Litteratur

1. Hem E. Karantene - om mer enn sykdom. Tidsskr Nor Legeforen 2013; 133: 1851.

Dette er en redigert versjon av debatten, publisert som rask respons på nett 23.9.2013. http://tidsskriftet.no/article/3062031/

\section{E. Hem svarer:}

Kolbein A. Finsnes og jeg kan fort bli enige om at «mayday» og «pan» kommer fra fransk. «Mayday», internasjonalt nødsignal fastsatt i 1948, er omdannet av «m'aidez» eller «m'aider»: «hjelp meg» $(1,2)$. «Pan pan» brukes når fartøy trenger assistanse, men ikke er i fare, og kommer fra panne: «svikt, stillstand» $(3,4)$.

Litt vanskeligere er det med ordet «karantene». I enkelte ordbøker står det, slik Finsnes nevner, at opphavet er fransk (5). Men ifølge den autoritative Oxford English Dictionary er det «probably Italian». Ordet skal stamme fra en venetiansk dialekt: «quarentena» (6). Visstnok var det i Venezia man innførte de første karantenebestemmelsene i kjølvannet av svartedauden.

Til å begynne med var isolasjonsperioden 30 dager, italiensk «trentina». En av de første som brukte begrepet på engelsk, var dagbokforfatteren Samuel Pepys (1633-1703). Så sent som i 1660-årene skrev han om en karantene «for 30 days» (6).
Finsnes mener at det verken var 30 eller 40, men 41 dager som gjaldt. Jeg finner ikke belegg for det i noen av de kildene jeg har tilgang til.

\section{Erlend Hem}

erlend.hem@legeforeningen.no

Erlend Hem (f. 1970) er assisterende sjefredaktør i Tidsskrift for Den norske legeforening.

Ingen oppgitte interessekonflikter.

\section{Litteratu}

1. Mayday. I: Noreng H. red. Norsk riksmålsordbok. Bd. 6: hohenstaufer-å-y. Oslo: Kunnskapsforlaget, 1995: 1832.

2. Mayday. I: Oxford English Dictionary. 3. utg., 2001. www.oed.com/view/Entry/ 115299 (12.10.2013).

3. Pan. I: Oxford English Dictionary. 3. utg., 2005. www.oed.com/view/Entry/248131 (12.10.2013)

4. Vedlegg I. Signaler. FOR 2003-02-07 nr. 252: Forskrift om lufttrafikkregler. www.lovdata.no/for/sf/sd/td-20030207-0252-012.html (12.10.2013).

5. Becker-Christensen C. red. Politikens nudansk ordbog med etymologi. 4. utg København: Politiken, 2010: 708

6. Quarantine. I: Oxford English Dictionary. 3. utg., 2007. www.oed.com/view/Entry/ 155959 (12.10.2013).

Dette er en redigert versjon av debatten, publisert som rask respons på nett 12.10.2013. http://tidsskriftet.no/article/3062031/ 